\title{
Scavengers flesh flies (Diptera, Sarcophagidae) from two phytophysiognomies in the state of Maranhão, Northeastern of Brazil
}

\author{
Raimundo Francisco Oliveira Nascimento ${ }^{1,2,3}{ }^{\circledR}$, José Orlando de Almeida Silva ${ }^{1,2,3}$ \& Fernando da Silva \\ Carvalho-Filho ${ }^{3 *(1)}$ \\ ${ }^{1}$ Universidade Federal do Maranhão, Curso de Licenciatura em Ciências Naturais/Biologia, Campus de Codó, \\ Codó, MA, Brasil. \\ ${ }^{2}$ Universidade Federal do Pará, Instituto de Ciências Biológicas, Departamento de Zoologia, Programa de \\ Pós-Graduação em Zoologia, Belém, PA, Brasil. \\ ${ }^{3}$ Museu Paraense Emílio Goeldi, Departamento de Zoologia, Laboratório de Entomologia, Programa de Pós- \\ Graduação em Zoologia, Belém, PA, Brasil. \\ *Corresponding author:fernanbio@yahoo.com.br
}

NASCIMENTO, R.F.O., SILVA, J.O.A., CARVALHO-FILHO, F.S. Scavengers flesh flies (Diptera, Sarcophagidae) from two phytophysiognomies in the state of Maranhão, Northeastern of Brazil. Biota Neotropica 21(4): e20211192. https://doi.org/10.1590/1676-0611-BN-2021-1192

\begin{abstract}
Flesh flies (Sarcophagidae) have been found in a wide range of natural and anthropogenic environments, from forests to deserts. The state of Maranhão, located in Northeastern Brazil, has a diverse phytogeography, but few faunistic studies have been conducted in this area. Therefore, the objective of this study was to inventory species of Sarcophagidae and compare abundance patterns between the Cerrado (savanna-like vegetation) and riparian forests in the municipality of Codó, state of Maranhão. Twelve sampling events were carried out from the second half of 2015 to the first half of 2017. This resulted in 3,220 specimens, $27.15 \%$ of which were males, from nine genera and 27 species. A total of 491 specimens (16 species) were collected in the Cerrado, and 383 specimens (21 species) in the riparian forest. Peckia (Sarcodexia) lambens (Wiedemann) was the most abundant species $(56,18 \%$ of the specimens sampled), followed by Peckia (Peckia) pexata (Wulp) (13\%); Peckia (Euboettcheria) collusor (Curran \& Walley) (13\%), and Peckia (Peckia) chrysostoma Wiedemann (10\%). Only P. (E.) collusor was found in greater abundance in the Cerrado. Oxysarcodexia angrensis (Lopes), Peckia (Peckia) enderleini (Engel), and Retrocitomiya andina Lopes are all new records to Maranhão and the entire Northeast Region of Brazil. Titanogrypa (Cuculomyia) albuquerquei (Lopes) is also a new to Maranhão.
\end{abstract}

Keywords: Calyptratae, cerrado; insects; inventory; Oestroidea; riparian forest.

\section{Moscas necrófagas (Diptera, Sarcophagidae) de duas fitofisionomias no estado do Maranhão, Nordeste do Brasil}

\footnotetext{
Resumo: As moscas Sarcophagidae podem ser encontradas em vários tipos de ambientes, naturais ou antropizados, desde florestas até desertos. O estado brasileiro do Maranhão, localizado na Região Nordeste, possui uma grande variedade de áreas fitogeográficas, mas poucos estudos faunísticos tem sido realizados nesta região. Portanto, o objetivo deste estudo foi inventariar as espécies de sarcofagídeos e comparar os seus padrões de abundância entre as áreas de cerrado (vegetação tipo savana) e de mata ciliar do município de Codó, estado do Maranhão. Foram realizadas 12 coletas, do segundo semestre de 2015 ao primeiro semestre de 2017 . Foram coletados 3.220 espécimes, dos quais $27,15 \%$ são machos, representados por nove gêneros e 27 espécies. No cerrado foram coletados 491 espécimes (16 espécies), na mata ciliar foram coletados 383 espécimes (21 espécies). As espécies mais abundantes foram Peckia (Sarcodexia) lambens (Wiedemann) (56,18\% dos indivíduos amostrados), Peckia (Peckia) pexata (Wulp) (13\%), Peckia (Euboettcheria) collusor (Curran \& Walley) (13\%) e Peckia (Peckia) chrysostoma Wiedemann (10\%). Apenas P. (E.) collusor foi significativamente mais abundante na área de cerrado. Oxysarcodexia angrensis (Lopes), Peckia (Peckia) enderleini (Engel) e Retrocitomiya andina Lopes são novos registros para a Região Nordeste do Brasil e Titanogrypa (Cuculomyia) albuquerquei (Lopes) é novo registro para o estado do Maranhão. Palavras-chave: Caliptradas; cerrado; insetos; inventario; Oestroidea; floresta ripária.
} 


\section{Introduction}

Sarcophagidae, or flesh flies, is one of the most diverse families of Calyptratae flies, with over 3,100 species divided into three subfamilies: Miltogramminae, Paramacronychiinae, and Sarcophaginae (Pape et al. 2011, Piwczynski et al. 2017). The Neotropical Region harbors one of the most diverse Sarcophagidae faunas, with over 800 species, many of which belong to the subfamily Sarcophaginae (Pape 1996, Pape $\&$ Dahlem 2010). There is only one species of Paramacronychiinae, which is found in the Galapagos Islands, and only a few species Miltogramminae are known to exist in this region (Pape 1996). In Brazil, which has one of the most diverse fauna of Sarcophagidae, the Sarcophaginae account for $94 \%$ of the species (Mello-Patiu 2020).

In the larval stage, flesh flies have the most diverse feeding habits among all Calyptratae fly families (Dahlem 1991, Pape \& Dahlem 2010). Most larvae of Miltogramminae are kleptoparasites in solitary hymenopteran nests; however, there are also scavenger species (Piwczynski et al. 2017). The larvae of the Paramacronychiinae and Sarcophaginae can be saprophagous, coprophagous, kleptoparasites in hymenopteran nests, predators of other insects' eggs, parasitoids of other arthropods, and vertebrate parasites (Shewell 1987, Dahlem 1991, Pape \& Dahelm 2010).

The larvae of several Sarcophaginae species are scavengers, meaning they feed on decomposing tissues of dead animals, including humans (Pape \& Dahlem 2010). Adults can be found on or near carcasses, which serve as a food source, breeding site, and substrate for immature development. This is why flesh flies are considered to be one of the most important indicators in forensic studies (Guo et al. 2014, Sharma et al. 2015, Fakoorziba et al. 2017, Pavaraj et al. 2018, Jang et al. 2019, Oliveira et al. 2019, Vairo \& Moura 2021). Furthermore, Sarcophaginae are an ideal taxonomic group for ecological studies because they can be easily collected in a variety of environments using traps containing decomposing organic matter (Sousa et al. 2016).

Flesh flies are found on all continents and in a wide range of terrestrial environments, from deserts to various types of forests (Shewell 1987). While some species can be found in several different habitats, others are restricted to a few specific locations (Carvalho-Filho et al. 2017, Camargo et al. 2018). Several Sarcophagidae species prefer open and sunny environments, such as pastures and forest clearings, and some of them have successfully colonized urban areas (Mulieri et al. 2011, Sousa et al. 2011, 2016, Vasconcelos et al. 2014).

Brazil is the largest country in South America; hence, it is home to a diverse range of habitats and plant communities, some of which are endemic, such as the Caatinga, an arid ecoregion in Northeastern Brazil (Silva et al. 2017, Tabarelli et al. 2018). The Cerrado, which is similar to African savannas and has direct contact with other biomes, is one of Brazil's most common vegetation types (Viera et al. 2019, Dutra \& Silva 2020). The Cerrado has a diverse phytophysiognomy, ranging from more open vegetation types, such as "campo limpo", "campo sujo", and "cerrado" sensu stricto, to more dense vegetation types, such as riparian forests surrounding streams, rivers, and lakes (Werneck 2011, Araújo et al. 2016, Rios et al. 2016, Silva et al. 2017, Eloy et al. 2019, Zuin 2020). The vegetation is denser in the riparian forest, with small and large trees growing close together under compact canopies (Castro et al. 2012, Kuntschik et al. 2014). Because riparian forests are an intermediate environment between the open Cerrado and more highly forested areas, species from both habitats can be found there (Silva et al. 2017, Dufek et al. 2020a). As a result, these environments are critical for the preservation of biodiversity, as well as serving as ecological corridors between many types of habitats (Silva et al. 2017).

Many studies on the Sarcophagidae fauna of the Cerrado have been conducted in various regions of Brazil, particularly in the CentralWest and Southeast areas (Rosa et al. 2011, Mello-Patiu et al. 2014, Paseto et al. 2019, Toma et al. 2020). Sousa et al. (2016) carried out a comprehensive research on the scavenger Sarcophagidae fauna in several types of phytophysiognomy, including the Cerrado in the northeastern Brazilian state of Maranhão. However, none of these studies addressed the fauna of the riparian forest. Therefore, the goal of this study is to inventory the scavenger Sarcophagidae species and compare their abundance patterns in "cerrado" sensu stricto and riparian forest areas in the eastern portion of the state of Maranhão, in a transition zone between the Cerrado and the Caatinga biomes.

\section{Material and Methods}

\section{Study area}

This study was carried out in the municipality of Codó ( $04^{\circ} 28^{\prime} 57,54805^{\prime \prime}$ $\left.\mathrm{S} ; 43^{\circ} 55^{\prime} 03,84603^{\prime \prime} \mathrm{W}\right)$, located in the eastern portion of the state of Maranhão, Northeastern Brazil, in an area of "cerrado" sensu stricto, on the villages of Roncador and Mirindiba, at the margins of the BR316 road, in areas of riparian forests surrounding the rivers Saco and Codozinho, both tributaries of the Itapecuru river (IBGE, 2019a) (Figure 1). The municipality has a land area of 4,361 $\mathrm{km}^{2}$ (IBGE, 2019), with the Cerrado as its main phytogeographic domain, with different phytophysiognomies depending on the region's ground topography "campo cerrado", "cerrado" sensu stricto and "cerradão" (Feitosa \& Almeida 2002, Correia-Filho 2011, Lopes Sobrinho et al. 2014). Furthermore, the region also harbors riparian forests, gallery forests, and babassu forest, which are overshadowed by the babassu palm tree (Attalea speciosa Mart. ex Spreng) (Correia-Filho 2011). The climate of the region is subhumid and semiarid, with total annual precipitation ranging between 1200 and $2000 \mathrm{~mm}$. The wet season lasts from December to May, and the dry season from June to November. The annual average temperature varies between $26^{\circ} \mathrm{C}$ and $27^{\circ} \mathrm{C}$, and the average relative humidity fluctuates between $65 \%$ and $85 \%$ (Correia-Filho 2011).

\section{Data collection}

We carried out 12 sampling events, two in the second half of 2015 , three in 2016, and seven in the first half of 2017. The Sarcophagidae were captured using fly traps similar to those described by Almeida et al. (2003) and baited with $50 \mathrm{~g}$ of bovine lungs. To kill all captured insects, we placed pyrethroid (k-othrine) insecticide-impregnated tape inside the collector bag. Traps were attached to tree branches 1.2 meters above ground. The minimum distance between traps was one kilometer, and each trap was left in the field for 48 hours. We set up 60 traps in total, 30 in Cerrado areas and 30 in riparian forest areas. In each sampling event, we set up five traps per area.

The Sarcophagidae were separated, labeled, identified, and counted at the Federal University of Maranhão (UFMA), Codó Campus, state of Maranhão, Brazil. Because the main characteristics used to identify the species are based on the male terminalia, only males were identified at species level. The following studies were used for identification: Lopes (1956, 1976), Guimarães (2004), Carvalho \& Mello-Patiu (2008), Vairo et al. (2011, 2015), Buenaventura \& Pape (2013), Mulieri et al. (2016), Mello-Patiu \& Salazar- 


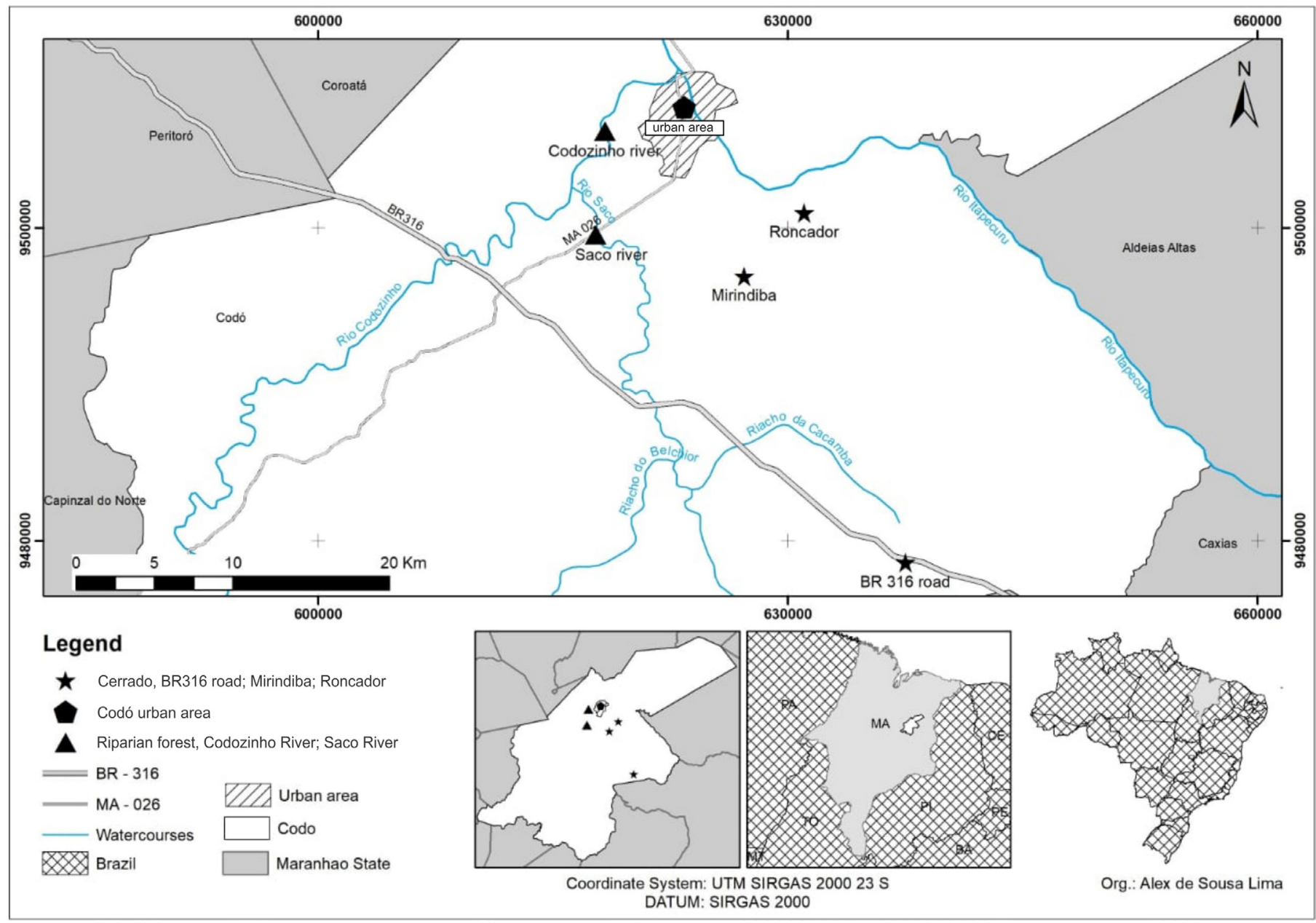

Figure 1. Location of the study area in the municipality of Codó, state of Maranhão, Brazil. Source: IBGE, 2019b (Modified by A.S. Lima).

Souza (2016), and Souza et al. (2020). We also compared our samples to specimens identified in the entomological collection of the Museu Paraense Emlio Goeldi (MPEG) in Belém, state of Pará, Brazil. All specimens were either deposited in the Coleção Zoológica do Maranhão (CZMA) of the State University of Maranhão (UEMA), at the Caxias Campus, or in the MPEG.

\section{Data analysis}

The abundance of each species was used as a continuous dependent variable, and the different habitat types as categorical independent variables (two levels: Cerrado and riparian forest). Each trap in each sampled area served as our sample unit. Before comparing the abundance values for the most representative species (more than 40 sampled specimens) of both habitat types, we tested the premises of variance homogeneity (Levene test) and normality (Shapiro test). Because the premises were not met, we log-transformed the response variables and tested for the same premises; if they were met, we performed ANOVA for one factor. In this case, however, the chart was created using data from the non log-transformed response variable in order to avoid the loss of biological effects of species abundance. When the premises were not satisfied even after transformation, we used data from the non-log-transformed response variable to perform the nonparametric Kruskal-Wallis test (Zar 2008). Using the R software, we performed statistical analysis and created charts (R Core Team 2020). When $p$-values were $\leq 0.05$, we considered the results significant.

\section{Results and Discussion}

We collected a total of 3,220 sarcophagid specimens, of which $2,346(72.85 \%)$ were female and $874(27.15 \%)$ were male (Table 1). Females were more abundant in carcasses and traps containing decomposing animal tissue because they use these substrates as larviposition sites and as a protein source for egg development (Ferraz 1992, Archer \& Elgar 2003, Bänziger \& Pape 2004). Thus, including females in the analyses can improve the reliability of the results regarding ecological and forensic issues. However, because there are few taxonomic tools that would allow us to identify female individuals, such as taxonomic keys and taxonomic descriptions, the majority of ecological and forensic studies on flesh flies only identify males to the genus or species level.

The males sampled belong to nine genera and 27 species, three of which (Oxysarcodexia angrensis (Lopes, 1933), Peckia (Peckia) enderleini (Engel, 1931), and Retrocitomyia andina (Lopes, 1985))

Table 1. Abundance of Sarcophagidae by genus in the study areas (cerrado and riparian forest), in the municipality of Codó, MA, Brazil.

\begin{tabular}{lccc}
\hline & \multicolumn{2}{c}{ COLLECTION AREA } & TOTAL \\
\cline { 2 - 3 } & Cerrado & Riparian forest & \\
\hline Females & 1.593 & 753 & 2.346 \\
Males & 491 & 383 & 874 \\
TOTAL & $\mathbf{2 . 0 8 4}$ & $\mathbf{1 . 1 3 6}$ & $\mathbf{3 . 2 2 0}$ \\
\hline
\end{tabular}


are new records for the Northeast Region, and one (Titanogrypa (Cuculomyia) albuquerquei (Lopes, 1976)) is a new record for the state of Maranhão (Table 2). Peckia (P.) enderleini has been found primarily in the southern South America (Argentina, Paraguay, Bolivia, and Brazil (states of Mato Grosso, Mato Grosso do Sul, Rio Grande do Sul, and São Paulo)) (Buenaventura \& Pape 2013, Toma et al. 2020). Therefore, this is the most northern-located record for this species in the continent. This species was also one of the most abundant among the scavenger sarcophagids sampled with traps containing bovine liver in a Cerrado area of the state of Mato Grosso do Sul (Toma et al. 2020), indicating a preference for this habitat type. However, we only found one specimen in the current study, which could be attributed to the type of bait used or to environmental conditions, as the Cerrado areas of Maranhão are drier than those in the state of Mato Grosso do Sul.

Retrocitomyia andina has been recorded in Bolivia and Peru (MelloPatiu \& Salazar-Souza 2016), but it was recently found in Amazonian grasslands in Brazil (Souza 2018). These grasslands are dry habitats, similar to Cerrado areas, implying that this species may be associated with these types of habitats, as has been observed for other Retrocitomyia species (e.g., Retrocitomyia mizuguchiana Tibana \& Xerez, 1985).

Oxysarcodexia angrensis is found in a wide distribution, ranging from Central America (Costa Rica and Panama) to Southeast Brazil (São Paulo), but it had yet to be recorded in the Brazilian Northeast Region. Titanogrypa (C.) albuquerquei had previously been recorded in the Bahamas, Cuba, and Brazil, but only in the Brazilian state of Piauí (Pape 1996). As a result, Maranhão is the second Brazilian state where this species has been recorded. The presence of new records indicates that the Sarcophagidae fauna in Brazil's Northeast Region is diverse but still understudied, as previously highlighted by other authors (Barbosa et al. 2015, Sousa et al. 2015).

Peckia (eight species) and Oxysarcodexia (eight species) were the genera with highest species richness. These were also the most abundant genera, with 801 (91.64\%) Peckia and 46 (5.26\%) Oxysarcodexia specimens

Table 2. Composition and abundance of Sarcophagidae species collected in the cerrado and riparian forest in the municipality of Codó, MA, Brazil. * First record for Northern Region. ** First record for state of Maranhão.

\begin{tabular}{|c|c|c|c|}
\hline \multirow{2}{*}{ SPECIES } & \multicolumn{2}{|c|}{ COLLECTION AREA } & \multirow[t]{2}{*}{ TOTAL } \\
\hline & Cerrado & Riparian forest & \\
\hline Blaesoxipha (Gigantotheca) stallengi (Lahille, 1907) & 1 & 0 & 1 \\
\hline Lipoptilocnema misella (Lopes, 1938) & 0 & 1 & 1 \\
\hline Oxysarcodexia amorosa (Schiner,1868) & 0 & 1 & 1 \\
\hline Oxysarcodexia avuncula (Lopes, 1933) & 0 & 1 & 1 \\
\hline Oxysarcodexia fringidea (Curran \& Walley, 1934) & 0 & 2 & 2 \\
\hline Oxysarcodexia modesta Lopes, 1946 & 1 & 4 & 5 \\
\hline Oxysarcodexia thornax (Walker, 1849) & 1 & 29 & 30 \\
\hline Peckia (Peckia) chrysostoma (Wiedemann, 1830) & 9 & 77 & 86 \\
\hline Peckia (Peckia) enderleini (Engel, 1931)* & 0 & 1 & 1 \\
\hline Peckia (Peckia) pexata (Wulp, 1895) & 72 & 42 & 114 \\
\hline Peckia (Peckia) uncinata (Hall, 1933) & 0 & 2 & 2 \\
\hline Peckia (Sarcodexia) lambens (Wiedemann, 1830) & 300 & 181 & 481 \\
\hline Peckia (Squamatodes) ingens (Walker, 1849) & 0 & 1 & 1 \\
\hline Peckiamyia abnormalis (Hall, 1937) & 1 & 0 & 1 \\
\hline Ravinia belforti (Prado \& Fonseca, 1932) & 1 & 0 & 1 \\
\hline Titanogrypa (Cuculomyia) luculenta (Lopes, 1938) & 0 & 3 & 3 \\
\hline TOTAL & 491 & 383 & 874 \\
\hline
\end{tabular}


(Table 2). Likewise, they were the most diverse genera in studies conducted in other Cerrado areas in the state of Maranhão (Sousa et al., 2015, 2016), the Central-West (Mello-Patiu et al. 2017, Toma et al. 2020), and Southeast regions of Brazil (Rosa et al. 2011, Mello-Patiu et al. 2014), as well as for other biomes, such as the Amazon Rainforest (Sousa et al. 2011) and the Atlantic Forest (Leandro \& D'Almeida 2005, Barbosa et al. 2014, Lopes et al. 2018). Peckia and Oxysarcodexia are two of South America's most speciesrich genera (Buenaventura \& Pape 2013, Souza et al. 2020), and many of its species have scavenger larvae (Pape \& Dahlem 2010). They are among the most important genera in terms of forensic and ecological studies in the Neotropical Region due to their abundance, diversity, and scavenger habit.

The low abundance of Oxysarcodexia may be related to habitat type, as some species in this genus prefer forested environments (Valverde-Castro et al. 2017). Certain species sampled in this study were also found to be in low abundance in previous studies conducted in Cerrado areas using decomposing animal organic matter (Rosa et al. 2011, Toma et al. 2020). Furthermore, because some Oxysarcodexia species are coprophagous (Pape \& Dahlem 2010), the type of bait used may have influenced our results.

Peckia (Sarcodexia) lambens (Wiedemann, 1830) was the most abundant species found (56,18\% specimens sampled), followed by Peckia (Peckia) pexata (Wulp, 1895) (13\%), Peckia (Euboettcheria) collusor (Curran \& Walley, 1934) (13\%), and Peckia (Peckia) chrysostoma (Wiedemann, 1830) (10\%). The remaining species account for $9 \%$ of all sampled specimens (Table 2). Peckia $(S$.) lambens is native to the southern United States of America (USA), several Caribbean islands, nearly all of South America, and has been introduced to the Cook Islands and French Polynesia. This widespread distribution is most likely due to the species' high ecological plasticity, which allowed it to colonize a wide range of environments, including heavily populated ones (Camargo et al. 2018, Sousa et al. 2020); furthermore, its larvae consume a variety of food sources. They can be insect parasitoids, predators of dying scorpions and insects, cause myiasis in birds and mammals, and scavengers of dead vertebrates and invertebrates. As a result, this is one of the most abundant species used in ecological and forensic studies (Alves et al. 2014a, b, Vasconcelos et al. 2015, Sousa et al. 2016, Souza \& Zuben 2016, Dufek et al. 2020a). There was no difference in abundance between open habitats and riparian forests in Cerrado areas, as expected for a species with high ecological plasticity $\left(X^{2}\right.$ $=0.0611, \mathrm{df}=1, p=0.434$, Kruskal-Wallis nonparametric test) (Figure 2).

Even though $P$. $(P$.) pexata has a wide distribution, ranging from Texas to Argentina, and can be found in both forested and open habitats (Ferreira 1979, Linhares 1981, Couri et al. 2000, Sousa et al. 2011, 2016, Valverde-Castro et al. 2017, Dufek et al. 2020b), it is not commonly seen in primary forests (Camargo et al. 2018). Hence, it may be associated with open and dry environments, such as the Cerrado and grasslands (Barros et al. 2008, Carvalho-Filho et al. 2018, Toma et al. 2020). Nevertheless, it was abundant in both open habitats and riparian forests in the studied area, with no significant differences between them (One-way ANOVA: $F_{(1,58)}=2.370, p=0.129$ ) (Figure 3).

Peckia (E.) collusor is a generalist species that can be found in a variety of habitats, including urban forests (Linhares 1981, D'Almeida 1984, Dias et al. 1984, Yepes-Gaurisas et al. 2013), open vegetation, and urban areas (Sousa et al. 2011, 2016, Mello-Patiu et al. 2014). Nevertheless, the difference in abundance between open areas and the riparian forest was significant in our study $\left(X^{2}=4.769, \mathrm{df}=1, p=0.029\right.$, Kruskal-Wallis nonparametric test $)$ (Figure 4). Sousa et al. (2016) and Valverde-Castro et al. (2017) also sampled fewer specimens of this species in forested habitats than in open habitats.

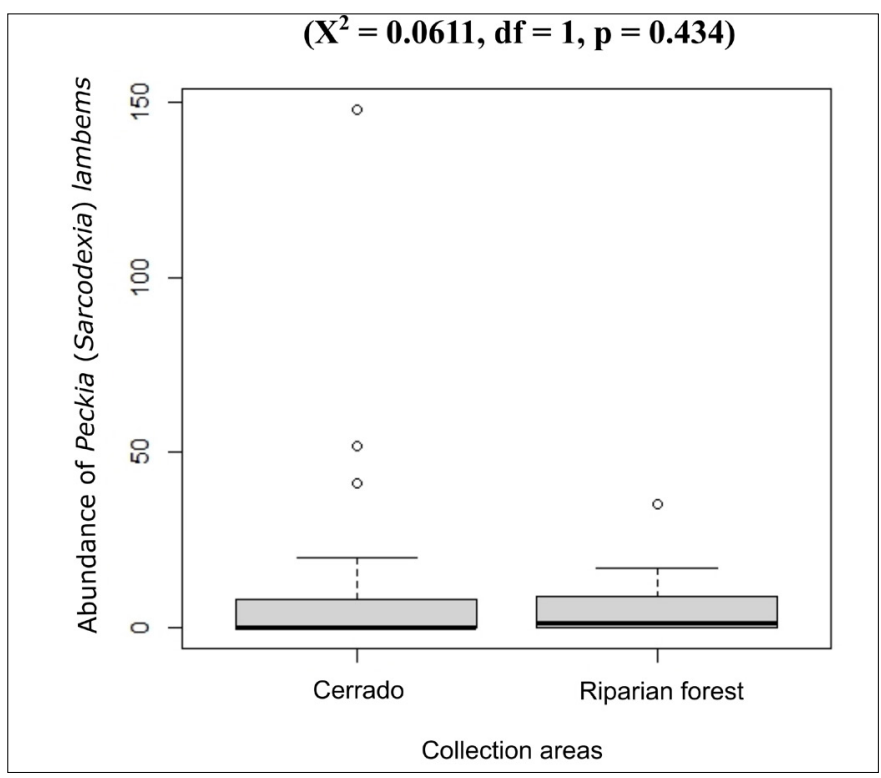

Figure 2. Relationship between the abundance of Peckia (Sarcodexia) lambens and the collection areas habitats (Cerrado and Riparian forest), in Codó municipality, Maranhão. Medians of the abundances between the two habitat types were not significantly different $(\mathrm{p}>0.05$; the Kruskal-Wallis two-tailed test). Data: $-=$ median; $\square 25 \%-75 \%$ 工 Min-Max $;^{\circ}=$ Outlier.

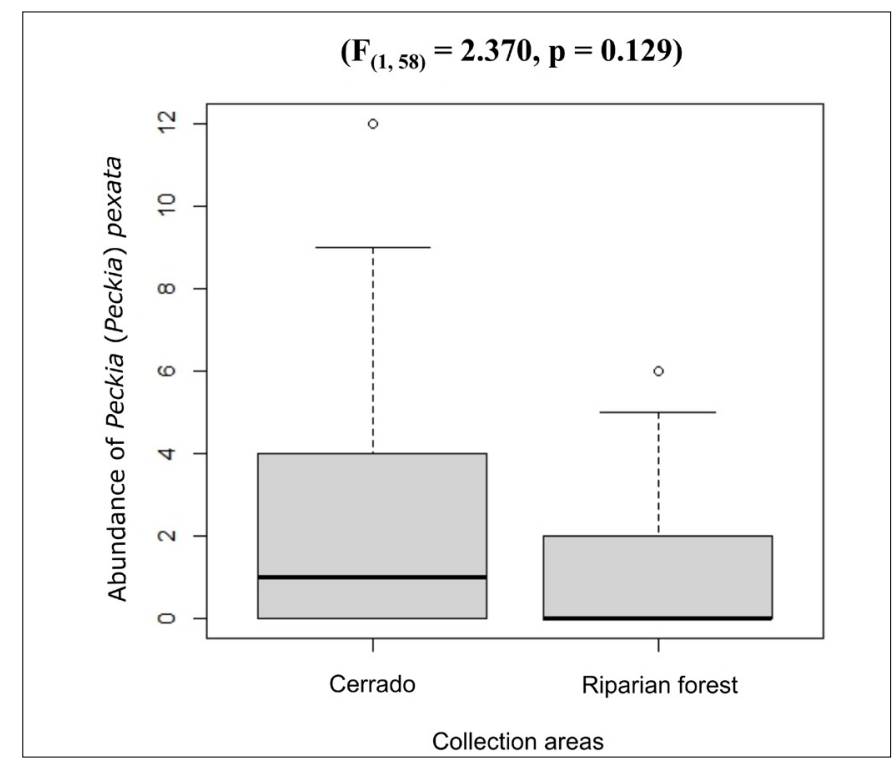

Figure 3. Relationship between the abundance of Peckia (Peckia) pexata and the collection areas habitats (Cerrado and Riparian forest), in Codó municipality, Maranhão. Means of the abundances between the two habitat types were not significantly different ( $>0.05$; ANOVA one-way test). Data: $-=$ means; $\square 25 \%-75 \%$ 工 Min-Max $;^{\circ}=$ Outlier.

Peckia (P.) chrysostoma is a widely distributed species (found from Southern United States to Southern Brazil) and an important representative of the scavenger fauna in Brazil, where it can be found in a variety of habitats, including cities (Yepes-Gaurisas et al. 2013, Carmo \& Vasconcelos 2016, Barbosa et al. 2017). Therefore, it is consistently one of the most abundant species in ecological and forensic studies in South America (Alves et al. 2014a, b, Sousa et al. 2016, ValverdeCastro et al. 2017). This species was abundant in both open and riparian habitats, with no significant differences between them $\left(X^{2}=0.073, \mathrm{df}=\right.$ $1, p=0.788$, Kruskal-Wallis nonparametric test) (Figure 5). 


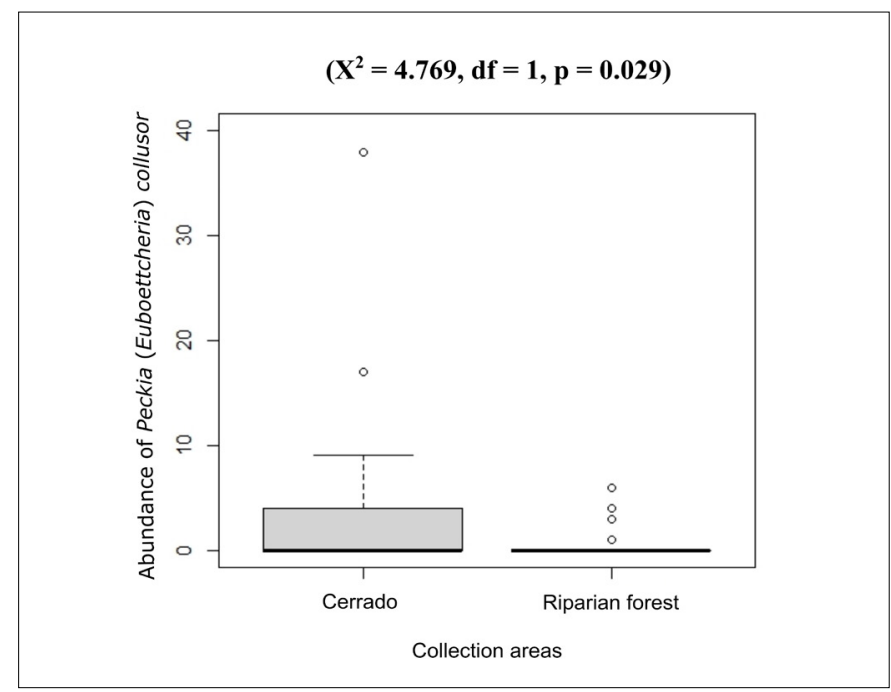

Figure 4. Relationship between the abundance of Peckia (Euboettcheria) collusor and the collection areas habitats (Cerrado and riparian Forest), in Codó municipality, Maranhão. Medians of the abundances between the two habitat types were significantly different $(\mathrm{p}<0.05$; Kruskal-Wallis two-tailed test). Dados: $-=$ median; $\square 25 \%-75 \%$ 工 Min-Max $;{ }^{\circ}=$ Outlier.

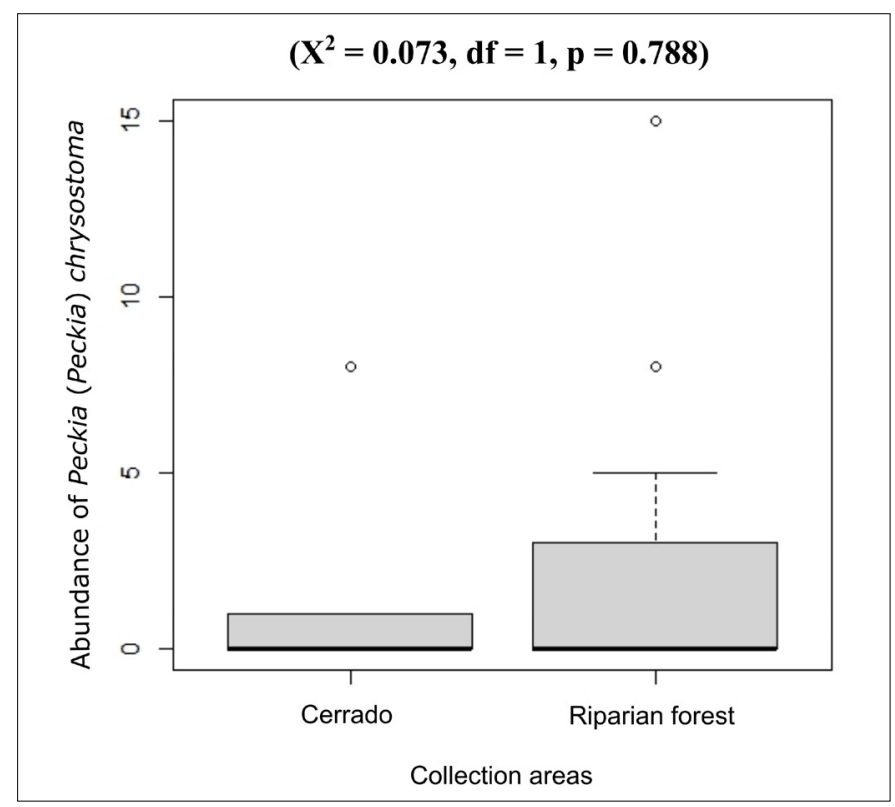

Figure 5. Relationship between the abundance of Peckia (Peckia) chrysostoma and the collection areas habitats (Cerrado and Riparian forest), in Codó municipality, Maranhão. Medians of the abundances between the two habitat types were not significantly different $(\mathrm{p}>0.05$; Kruskal-Wallis two-tailed test). Dados: $-=$ median; $\square 25 \%-75 \%$ 工 Min-Max $;{ }^{\circ}=$ Outlier.

Of the total number of specimens sampled, 2,084 were found in Cerrado areas and 1,136 in riparian forests. Flesh flies, both males and females, were more abundant in open areas of Cerrado. These findings are consistent with previous research, which found that species belonging to this family were more abundant in open environments (pastures, clearings, and savannas) than in adjacent forests (Sousa et al., 2011, 2016, Yepes-Gaurisas et al. 2013). The majority of the species of Sarcophagidae found in this study have a wide geographical distribution in both Brazil and South America, being present in various phytogeographic domains such as the Amazon Rainforest, Atlantic
Forest, Cerrado, and Caatinga (Alves et al. 2014a, b, Mello-Patiu et al. 2014, 2017, Sousa et al. 2016, Barbosa et al. 2017).

However, some of the species sampled, such as Lipoptilocnema misella (Lopes, 1938), R. mizuguchiana, and Blaesoxipha (Gigantotheca) stallengi (Lahille, 1907), are most likely associated with open and/or dry habitats. In a study conducted in different biomes of the state of Maranhão, R. mizuguchiana and B. (G.) stallengi were only sampled in savannas and swamps, which are open environments (Sousa et al. 2016). Lipoptilocnema misella was only identified in the Brazilian states of Goiás, Maranhão, Mato Grosso, and Minas Gerais (Mulieri et al. 2016, Sousa et al. 2016). Because this species, like many others in the same genus, is associated with Cerrado areas (Mulieri et al. 2016), it is absent in forensic studies and lists of scavenger flesh flies in the Amazon (Vairo et al. 2014, Ramos-Pastrana et al. 2018).

In Brazil, only two species of the subgenus Squamatodes are found: Peckia (Squamatodes) ingens (Walker, 1849) and Peckia (Squamatodes) trivittata (Curran, 1927), the former being more common in forested habitats and the latter in more open ones such as the Cerrado (Barros et al. 2008, Valverde-Castro et al. 2017, Camargo et al. 2018). This is most likely why the abundance of $P$. (S.) ingens was low in the studied area. Sousa et al. (2016), on the other hand, sampled 39 specimens in Cerrado areas and none in the Amazon rainforest in the state of Maranhão.

The species L. misella, Oxysarcodexia amorosa (Schiner, 1868), Oxysarcodexia avuncula (Lopes, 1933), Oxysarcodexia fringidea (Curran \& Walley, 1934), P. (P.) enderleini, Peckia (Peckia) uncinata (Hall, 1933), $P$. (S.) ingens, $R$. andina, Retrocitomyia retrocita (Hall, 1933), Titanogrypa (Cuculomyia) luculenta (Lopes, 1938) and Titanogrypa (Airypel) cryptopyga (Lopes, 1956), were found only in the riparian forest, although in low abundance (less than 5 specimens) (Table 2). According to Macedo (1993), Castro et al. (2012), and Kuntschik et al. (2014), riparian forests have great ecological importance because of their faunistic, floristic, and microbiotic composition, thus playing an important role in forming corridors that promote gene flow. The presence of species of Sarcophagidae in riparian forests that were absent in open areas, as well as new species records, suggest that this vegetation type is also important for the conservation of the family's biodiversity in the Cerrado. Nonetheless, anthropogenic activities, particularly logging, cattle raising, and agriculture, are drastically altering riparian forests in the municipality of Codó, because these areas typically have fertile soils (Castro 2012, Kuntschik et al. 2014, Kutzmy et al. 2019).

\section{Conclusions}

We identified 27 species of scavenger Sarcophagidae in the studied areas, three of them were new records for the Northeast Region (Oxysarcodexia angrensis, Peckia (Peckia) enderleini and Retrocitomiya andina), and one for the state of Maranhão (Titanogrypa (Cuculomyia) albuquerquei). This highlights the importance and necessity of conducting more surveys in the region, especially in areas such as riparian forests, where the sarcophagid fauna has not yet been adequately sampled. The habitat type only significantly affected the abundance of Peckia (Euboettcheria) collusor, which was more abundant in open areas. Peckia (Peckia) chrysostoma, P. (P.) pexata, and $P$. (S.) lambens were generalists in the studied areas. This study contributes to the understanding of the spatial distribution of different Sarcophagidae species in "cerrado" sensu stricto and riparian forest areas, reducing the knowledge gap for this group in the Northeast Region of Brazil. 


\section{Acknowledgments}

We thank Fundação de Amparo à Pesquisa e ao Desenvolvimento Científico e Tecnológico do Maranhão (FAPEMA), for the financial support for the realization of this research (FAPEMA $n^{\circ} 00811 / 15$ Universal) and for the publication of this article. JOAS is grateful to the FAPEMA for the doctoral research grant (Process $n^{\circ}$ BD-02769/20). We thank Cassio Lauande Araujo da Silva, Artemise Silva dos Reis, Isaura Vieira Lima, Lunnah Cynd da Costa Santos, Deborah Gomes Félix, César Alves da Silva, Rafael Costa Bastos, Uerverson Silva de Almeida and Waldison de Jesus Carvalho Marques for their assistance in field work. We are also grateful to Dr. Alex de Sousa Lima for his assistance in preparing the map (Figure 1) with the collection areas.

\section{Author Contributions}

Raimundo Francisco Oliveira Nascimento: Substantial contribution in the concept and design of the study; Contribution to data collection; Contribution to data analysis and interpretation; Contribution to manuscript preparation; Contribution to critical revision, adding intellectual content.

José Orlando de Almeida Silva: Substantial contribution in the concept and design of the study; Contribution to data collection; Contribution to data analysis and interpretation; Contribution to manuscript preparation; Contribution to critical revision, adding intellectual content.

Fernando da Silva Carvalho-Filho: Contribution to data analysis and interpretation; Contribution to manuscript preparation; Contribution to critical revision, adding intellectual content.

\section{Conflicts of Interest}

There is no conflict of interest.

\section{References}

ALMEIDA, I.M., RIBEIRO-COSTA, C.S. \& MARIONI, L. 2003. Manual de Coleta, conservação, montagem e identificação de insetos. Série Manuais Práticos em Biologia - 1, Ribeirão Preto, Holos Editora 78p.

ALVES, A.C.F., SANTOS, W.E. \& CREÃO-DUARTE, A.J. 2014a. Diptera (Insecta) de importância forense da região Neotropical. Entomotropica. 29: 77-94.

ALVES, A.C.F., SANTOS, W.E., FARIAS, R.C.A.P. \& CREÃO-DUARTE, A.J. 2014b. Blowflies (Diptera, Calliphoridae) associated with pig carcasses in a caatinga area, Northeastern Brazil. Neotro. Entomol. 43: 122-126.

ARAÚJO, A.S.F., SOUZA, D.G. \& LOPES, A.C.A. 2016. T-RFLP analysis of soil bacterial structure from cerrado within the Sete Cidades National Park, Brazil. Neotrop. Biodiver. 2(1): 163-170.

ARCHER, M.S. \& ELGAR, M.A. 2003. Female breeding-site preferences and larval feeding strategies of carrion-breeding Calliphoridae e Sarcophagidae (Diptera): a quantitative analysis. Aust. J. Zool. 51: 165-174.

BÄNZIGER, H. \& PAPE, T. 2004. Flowers, faeces and cadavers: natural feeding and laying habits of flesh flies in Thailand (Diptera: Sarcophagidae, Sarcophaga spp.). J. Nat. Hist. 38: 1677-1694.

BARBOSA, L.S., CUNHA, A.M., COURI, M.S. \& MAIA, V.C. 2014. Muscidae, Sarcophagidae, Calliphoridae e Mesembrinellidae (Diptera) da Estação Biológica de Santa Lúcia (Santa Teresa, Espírito Santo, Brasil). Bol. Mus. Biol. Melo Leitão 33: 131-140.
BARBOSA, T.M., CARMO, R.F.R., SILVA, L.P., SALES, R.G. \& VASCONCELOS, S.D. 2017. Diversity of sarcosaprophagous Calyptratae (Diptera) on sandy beaches exposed to increasing levels of urbanization in Brazil. Environ. Entomol. 46: 460-469.

BARBOSA, T.M., MELLO-PATIU, C.A. \& VASCONCELOS, S.D. 2015. Flesh fly (Diptera: Sarcophagidae) survey on coastal environments in northeastern Brazil: new records and notes on the expanded geographical distribution. Entomotropica. 30: 112-117.

BARROS, R.M., MELlO-PATIU, C.A. \& PUJOL-LUZ, J.R. 2008. Sarcophagidae (Insecta, Diptera) associados à decomposição de carcaças de Sus scrofa Linnaeus (Suidae) em área de Cerrado do Distrito Federal, Brasil. Rev. Brasil. Entomol. 52: 606-609.

BUENAVENTURA, E. \& PAPE, T. 2013. Revision of the new world genus Peckia Robineau-Desvoidy (Diptera: Sarcophagidae). Zootaxa, 3622: 1-87.

CAMARGO, S.L.L.X., CARVALHO-FILHO, F.S. \& ESPOSITO, M.C. 2018. The genus Peckia Robineau-Desvoidy (Diptera: Sarcophagidae) in the Brazilian Amazon: a new species, new records, descriptions of female terminalia and key to species. Zootaxa, 4483: 001-035.

CARMO, R.F.R. \& VASCONCELOS, S.D. 2016. Assemblage of necrophagous Diptera in Atlantic insular environments and response to different levels of human presence. Neotrop. Entomol. 45: 471-481.

CARVALHO, C.J.B. \& MELLO-PATIU, C.A. 2008. Key to the adults of the most common forensic species of Diptera in South America. Rev. Brasil. Entomol. 52: 390-406.

CARVALHO-FILHO, F.S., GORAYEB, I.S., SOARES, J.M.M. \& SOUZA, M.T. 2018. Flesh flies (Diptera: Sarcophagidae) from a white-sand habitat in the Brazilian Amazon, with the description of four new species. Zootaxa, 4504: 401-417.

CARVALHO-FILHO, F.S., SOUZA, C.C. \& SOARES, J.M.M. 2017. A new species of Sarcofahrtiopsis (Insecta, Diptera, Sarcophagidae) from mangrove forests in the Brazilian Amazon, with a key to species identification. Acta Amazonica. 47: 349-354.

CASTRO, D., MELLO, S.P. \& POESTER, G.C. 2012. Práticas para restauração da mata ciliar. Porto Alegre, Catarse - Coletivo de Comunicação. 64p.

CORREIA-FILHO, F.L., GOMES, E.R., NUNES, O.O. \& LOPES FILHO, J.B. 2011. Projeto cadastro de fontes de abastecimento por água subterrânea, estado do Maranhão: Relatório diagnóstico do município de Codó. CPRM - Serviço Geológico do Brasil, Teresina, 42p.

COURI, M. S., LAMAS, C.J.E., AIRES, C.C.C.A., MELLO-PATIU, C. A., MAIA, V. C., PAMPLONA, D. M. \& MAGNO, P. 2000. Dípteros da Serra do Navio (Amapá, Brasil): Asilidae, Bombyliidae, Calliphoridae, Micropezidae, Muscidae, Sarcophagidae, Stratiomyiidae, Syrphidae, Tabanidae e Tachinidae. Rev. Bras. Zoociências 2: 91-100.

DAHLEM, G.A. 1991. Sarcophagidae (Oestroidea). In Immature Insects, vol. 2 (FW, Stehr, ed). Kendall/Hunt Publishing Company, Dubuque, p.871-873.

D'ALMEIDA, J.M 1984. Sinantropia de Sarcophagidae (Diptera) na região metropolitana do Estado do Rio de Janeiro. Arq. Univ. Fed. Rur. Rio J. 7: 101-110.

DIAS, E.S., NEVES, D.P. \& LOPES, H.S. 1984. Estudos sobre a fauna de Sarcophagidae (Diptera) de Belo Horizonte, Minas Gerais. I - Levantamento taxonômico e sinantrópico. Mem. Inst. Oswaldo Cruz, 79: 83-91.

DUFEK, M.I., LARREA, D.D., DAMBORSKY, M.P. \& MULIERI, P.R. 2020a. The effect of anthropization on Sarcophagidae (Diptera: Calyptratae) community structure: An assessment on different types of habitats in the humid Chaco ecoregion of Argentina. J. Med. Entomol. 20: 1-12.

DUFEK, M.I., MELLO-PATIU, C.A. \& MULIERI, P.R. 2020b. Inventory of Sarcophaginae (Diptera: Sarcophagidae) for the Humid Chaco, a poorly surveyed ecoregion of South America. J. Nat. Hist. 54(5-6): 367-403. DO I: $10.1080 / 00222933.2020 .1764646$

DUTRA \& SILVA, S. 2020. Challenging the environmental history of the Cerrado: Science, biodiversity and politics on the Brazilian agricultural frontier. Halac. 10: 82-116.

ELOY, L., SCHMIDT, I.B., BORGES, S.L.; FERREIRA, M.C \& SANTOS, T.A. 2019. Seasonal fire management by traditional cattle ranchers prevents the spread of wildfire in the Brazilian Cerrado. Ambio. 48: 890-899. 
FAKOORZIBA, M.R., ASSAREH, M., KESHAVARZI, D., SOLTANI, A., FARD, M.D.M. \& ZARENEZHAD, M. 2017. New record of Sarcophaga ruficornis, Fabricius, 1794 (Diptera: Sarcophagidae) from Iran, a flesh fly species of medical and forensic importance. J. For. Sci. Crim. Invest. 3(1): JFSCI.MS.ID.555602.

FEITOSA, A.C. \& ALMEIDA, A.P. 2002. A degradação ambiental do rio Itapecuru na sede do município e Codó - MA. Caderno de Pesquisa. 13: $31-45$

FERRAZ, M.V. 1992. Comparison of the reproductive behavior between isolated Peckia chrysostoma (Wiedemann, 1830) and Adiscochaeta ingens (Walker, 1849) (Diptera: Sarcophagidae) females reared in laboratory. Mem. Inst. Oswaldo Cruz, 87: 131-139.

FERREIRA, M.J.M. 1979. Sinantropia de dípteros muscóides de Curitiba, Paraná. II. Sarcophagidae. Rev. Brasil. Biol. 39: 773-781.

GUIMARÃES, H.J.L. 2004. Redescrição dos machos de dez espécies neotropicais de Ravinia Robineau-Desvoidy, 1863 (Diptera, Sarcophagidae). Arq. Museu do Nacional, 62: 45-66.

GUO, Y., ZHA, L., YAN, W., LI, P., CAI, J. \& WU, L. 2014. Identification of forensically important sarcophagid flies (Diptera: Sarcophagidae) in China based on COI and period gene. Inter. J. Leg. Med. 128: 221-228.

IBGE. Instituto Brasileiro de Geografia e Estatística. 2019a. Informações completas: Codó, Maranhão. Available in: http://www.cidades.ibge.gov. br/xtras/perfil.php?lang=\&codmun=210330\&search=||infogr\%E1ficos:inf orma $\%$ E7\%F5es-completas (Last access in 10/10/2019).

IBGE. Instituto Brasileiro de Geografia e Estatística. 2019b. Malhas: municípios do Estado do Maranhão e Brasil administrativo. Available in: https:/www.ibge.gov.br/ geociencias/organizacao-do-territorio/15774-malhas. $\mathrm{html} ?=\& \mathrm{t}=$ downloads (Last access in 05/01/2021).

JANG, H., SHIN, S.E., SOO KO, K. \& PARK, S.H. 2019. SNP typing using multiplex real-Time PCR assay for species identification of forensically important blowflies and flesh flies collected in south Korea (Diptera: Calliphoridae and Sarcophagidae). BioMed Resear. Inter. Available in: https:// doi.org/10.1155/2019/6762517 (Last access in 28/12/2020).

KUNTSCHIK, D.P. 2014. Matas Ciliares. Secretaria do Meio Ambiente, Coordenadoria de Biodiversidade e Recursos Naturais. São Paulo, SMA. $82 \mathrm{p}$.

KUTZMY,A.M.,ANTONELI, V. \& MAGANHOTTO, R.F. 2019. Características da mata ciliar em diferentes usos da terra e os conflitos de usos em faxinal. Boletim de Geografia. 37: 32-49.

LEANDRO, M.J.F. \& D'ALMEIDA, J.M. 2005. Levantamento de Calliphoridae, Fanniidae, Muscidae e Sarcophagidae em um fragmento de mata na Ilha do Governador, Rio de Janeiro, Brasil. Iheringia, Sér. Zool. 95: 377-381.

LINHARES, A.X. 1981. Synanthropy of Calliphoridae and Sarcophagidae (Diptera) in the city of Campinas, São Paulo, Brazil. Rev. Brasil. Entomol. 25: 189-215.

LOPES, D.S., OLIVEIRA, F.F., MELLO-PATIU, C.A., PAMPONET, F.M \& THÉ, T.S. 2018. Espécies de Oxysarcodexia (Diptera: Sarcophagidae) associada a carcaças de suínos (Sus scrofa Linnaeus) expostas em um fragmento de Mata Atlântica nenhum município de Salvador, Bahia. EntomoBrasilis. 11: 103-106.

LOPES, H.S. 1956. Sobre o gênero "Titanogrypa" Townsend, 1017 (Dipter, Sarcophagidae. Rev. Brasil. Entomol. 16: 207-211.

LOPES, H.S. 1976. On the genus Cuculomyia Roback (Diptera, Sarcophagidae). Rev. Brasil. Bio. 36: 745-757.

LOPES SOBRINHO, O.P., SOUSA, M.O., PEREIRA, A.I.S., SILVA, L.F.B., CARLOS, M.A.S., LOPES, M.A., SILVA, I.V.B. \& FERREIRA, J.C.S. 2014. A arborização urbana e os reflexos socioambientais: um estudo de caso no município de Codó (MA). Rev. Ibero-Americana C. Amb. 5: 19-26.

MACEDO, A.C. 1993. Restauração: matas ciliares e de proteção ambiental. São Paulo: Fundação Florestal, 27p.
MELLO-PATIU, C.A. 2020. Sarcophagidae. In Catálogo Taxonômico da Fauna do Brasil. PNUD. Available in: http://fauna.jbrj.gov.br/fauna/listaBrasil/ ConsultaPublicaUC/ConsultaPublicaUC.do (Last access in 28/12/ 2020).

MELLO-PATIU, C.A. \& SALAZAR-SOUZA, M. 2016. Retrocitomyia Lopes, 1982 (Diptera: Sarcophagidae): new species, new records, key to males, and an updated catalog. Zootaxa. 3: 534-548.

MELlO-PATIU, C.A., PASETO, M.L., FARIA, L.S., MENDES, J. \& LINHARES, A.X. 2014. Sarchophagid flies (Insecta, Diptera) from pig carcasses in Minas Gerais, Brazil, with nine new records from the Cerrado, a threatened Neotropical biome. Rev. Brasil. Entomol. 58: 142-146.

MELLO-PATIU, C.A., SILVA, K.P. \& VAIRO, K.P. 2017. Checklist dos Sarcophagidae (Insecta, Diptera) do estado do Mato Grosso do Sul, Brasil. Iheringia, Sér. Zool. 107(supl.): E2017142.

MULIERI, P.R., MELLO-PATIU, C.A. \& ABALLAY, F.H. 2016. Taxonomic revision of Lipoptilocnema (Diptera: Sarcophagidae), with notes on natural history and forensic importance of its species. J. Med. Entomol. 1-26.

MULIERI, P.R., PATITUCCI, L.D., SCHNACK, J.A. \& MARILUIS, J.C. 2011. Diversity and seasonal dynamics of an assemblage of Sarcophagid Diptera in a gradient of urbanization. J. Insect Sci. 11: 91

OLIVEIRA, C.A., FACCIN, S., THYSSEN, P.J., DIAS, D., KAAPOTHAKIS, E. \& REBELO, M.T. 2019. Complete mitochondrial genomes of three species of fresh flies of forensic entomology interest from the genus Sarcophaga (Sarcophagidae) from Portugal and Brazil. Mitoch. DNA Part B Resour. 4: 237-239.

PAPE, T. 1996. Catalogue of the Sarcophagidae of the World (Insecta: Diptera). Mem. Entomol. Int. 8: 1-558.

PAPE, T., BLAGODEROV, V. \& MOSTOVSKI, M.B. (2011) Order Diptera Linnaeus, 1758. In Animal biodiversity: An outline of higher-level classification and survey of taxonomic richness (ZHANG, Z.-Q. ed.). Zootaxa 3148: 222-229.

PAPE, T. \& DAHLEM, G.A. 2010. Sarcophagidae. In Manual of Central American Diptera II (B.V. Brown, A. Borkent, J.M. Cumming, D.M. Wood, N.E. Woodley \& M. Zumbado. eds.). NRC Press Research, Ottawa, p.1313-1335.

PASETO, M. L., FARIA, L. S., MENDES, J. \& LINHARES, A. X. 2019. Diversity of Sarcophagidae (Insecta, Diptera) associated with decomposing carcasses in a rural area of the State of Minas Gerais, Brazil. EntomoBrasilis. 12:118-125.

PAVARAJ, M., ESWARAN, K., KUMAR, A. \& RAJAN, M. K. 2018. Diversity of forensic insects in a rodent carcass. Inter. J. Entomol. Research, 3: 81-84.

PIWCZYŃSKI, M., PAPE, T., DEJA-SIKORA,E., SIKORA, M.,AKBARZADEH, K. \& SZPILA, K. 2017. Molecular phylogeny of Miltogramminae (Diptera: Sarcophagidae): implications for classification, systematics and evolution of larval feeding strategies. Molecular Phylogenetics and Evolution, DOI: http://dx.doi.org/10.1016/j.ympev.2017.07.001 (Last acess in 28/12/2020)

RAMOS-PASTRANA, Y., VIRGUEZ-DÍAZ, Y. \& WOLFF, M. 2018. Insects of forensic importance associated to cadaveric decomposition in a rural area of the Andean Amazon, Caquetá, Colombia. Acta Amazonica, 48: 126-136.

R CORE TEAM. 2020. R: A language and environment for statistical computing. R Foundation for Statistical Computing, Vienna, Austria. URL https:// www.R-project.org/ (Last acess in 16/09/2020).

RIOS, A.B.M., OLIVEIRA, J.P.S., SILVA, R.P., NETO, J.F.O., OLIVEIRA, L.S., PERALTA, D.F. \& MACCAGNAN, D.H.B. 2016. Bryophyte diversity in an area of Brazilian Cerrado in Central-West. Neotrop. Biol. Conserv. 11: $132-140$

ROSA, T.A., BARATA, M.L.Y., SOUSA, C.M., SOUSA, D., MELLO-PATIU, C.A., VAZ-DE-MELLO, F.Z. \& MENDES, J. 2011. Arthropods associated with pig carrion in two vegetation profiles of Cerrado in the state of Minas Gerais, Brazil. Rev. Brasil. Entomol. 55: 424-434.

SHARMA, M., SINGH, D. \& SHARMA, A.K. 2015. Molecular identification of forensically important Indian species of Flesh flies (Diptera: Sarcophagidae) by using COI gene of mitochondrial DNA. J. For. Resear. 6: 6 .

SHEWELL, G.E. 1987. Sarcophagidae. In Manual of Nearctic Diptera (J.F. McALPINE, ed.). Agriculture Canada, Monograph 2: p.1159-1186. 
SILVA, N.M., ANGEOLETTO, F., SANTOS, J.W.M.C., FILHO, A.C.P.; VACCHIANO, M.C.; BOHRER, J.F.C. \& CÂNDIDO, A.K.A.A. 2017. The negative influences of the new brazilian forest code on the conservation of riparian forests. Europ. J. Eco. 3: 116-122.

SOUSA, J.R.P., CARVALHO-FILHO, F.S. \& ESPOSITO, M.C. 2015. Distribution and abundance of necrophagous flies (Diptera: Calliphoridae and Sarcophagidae) in Maranhão, Northeastern Brazil. J. Insect Sci. 15: 70.

SOUSA, J.R.P., CARVALHO-FILHO, F.S., JUEN, L. \& ESPOSITO, M.C. 2016. Evaluating the efects of different vegetation types on necrophagous fly communities (Diptera: Calliphoridae; Sarcophagidae): implications for conservation. Plos One, 11: 10.

SOUSA, J.R.P., CARVALHO-FILHO, F.S., JUEN, L. \& ESPOSITO, M.C. 2020 The effects of cattle ranching on the communities of necrophagous flies (Diptera: Calliphoridae, Mesembrinellidae and Sarcophagidae)

in Northeastern Brazil. J. Insect Conservation. Available at: https://doi org/10.1007/s10841-020-00246-y (Last access in 28/12/2020).

SOUSA, J.R.P., ESPOSITO, M.C. \& CARVALHO-FILHO, F.S. 2011. Composition, abundance and richness of Sarcophagidae (Diptera: Oestroidea) in forests and forest gaps with different vegetation cover. Neotrop. Entomol. 40: 20-27.

SOUZA, C.C. 2018. Revisão taxonômica e análise filogenética das espécies de Retrocitomyia Lopes, 1983 (Diptera: Sarcophagidae). Dissertação de mestrado, Universidade Federal do Pará/Museu Paraense Emílio Goeldi, Pará.

SOUZA, C.M., PAPE, T. \& THYSSEN, P.J. 2020. Oxysarcodexia Townsend, 1917 (Diptera: Sarcophagidae) - a centennial conspectus. Zootaxa 4841(1): 1-126.

SOUZA, C.R. \& ZUBEN, C.J.V. 2016. Synanthropy of Sarcophagidae (Diptera) in southeastern Brazil. Noetrop. Entomol. 45: 637-641.

TABARELLI, M., LEAL, I.R., SCARANO, F.R. \& SILVA, J.M.C. 2018. Caatinga: legado, trajetória e desafios rumo à sustentabilidade. Cienc. Cult. [online]. 70: 25-29.

TOMA, R., KOLLER, W.W., MELLO-PATIU, C.A. \& MELLO, R.L. 2020. New records of Sarcophagidae (Insecta: Diptera) collected in cerrado fragments in the municipality of Campo Grande, Mato Grosso do Sul state, Brazil. EntomoBrasilis, 13: e0873.

VAIRO, K.P., MOURA, M.O. \& MELLO-PATIU, C.A. 2011. Pictorial identification key for species of Sarcophagidae (Diptera) of potential forensic importance in southern Brazil. Rev. Brasil. Entomol. 55: 333-347.

VAIRO, K.P., MOURA, M.O. \& MELLO-PATIU, C.A. 2015. Comparative morphology and identification key for females of nine Sarcophagidae species (Diptera) with forensic importance in Southern Brazil. Rev. Brasil. Entomol. 59: 177-187.
VAIRO, K.P. \& MOURA, M.O. 2021. Entomologia forense na prática - do laboratório à utilização do vestígio. 1. ed. Millennium, Campinas, 336p.

VAIRO, K.P., URURAHY-RODRIGUES, A., MOURA, M.O. \& MELLOPATIU, C.A. 2014. Sarcophagidae (Diptera) with forensic potential in Amazonas: a pictorial key. Tropical Zoology, 27: 140-152.

VALVERDE-CASTRO, C., BUENAVENTURA, E., SÁNCHEZ-RODRÍGUEZ, J.D. \& WOLFF, M. 2017. Flesh flies (Diptera: Sarcophagidae: Sarcophaginae) from the Colombian Guajira biogeographic province, an approach to their ecology and distribution. Zoologia, 34: e12277.

VASCONCELOS, S. D., BARBOSA, T.M. \& OLIVEIRA, T.P.B. 2015. Diversity of forensically-important dipteran species in different environments in northeastern Brazil, with notes on the attractiveness of animal baits. The Flor. Entomol. 98: 770-775.

VASCONCELOS, S.D., SOARES, T.F. \& COSTA, D.L. 2014. Multiple colonization of a cadaver by insects in an indoor environment: First record of Fannia trimaculata (Diptera: Fanniidae) and Peckia (Peckia) chrysostoma (Sarcophagidae) as colonizers of a human corpse. Inter. J. Leg. Med. 128: 229-233.

VIEIRA, L.T.A., CASTRO, A.A.J.F., COUTINHO, J.M.C.P., SOUSA, S.R., FARIAS, R.R.S., CASTRO, N.M. C.F. \& MARTINS, F.R. 2019. A biogeographic and evolutionary analysis of the flora of the North-eastern cerrado, Brazil. Plant. Eco. Diversity. DOI: 10.1080/17550874.2019.1649311 (Last access in 28/12/2020)

WERNECK, F.P. 2011. The diversification of eastern South American open vegetation biomes: Historical biogeography and perspectives. Quarter. Sci. Rev. 30: 1630-1648.

YEPES-GAURISAS, D., SÁNCHEZ-RODRÍGUEZ, J.D., MELLO-PATIU, C.A. \& ECHEVERRI, M.W. 2013. Synanthropy of Sarcophagidae (Diptera) in la Pintada, Antioquia-Colombia. Rev. Biol. Trop. 61: 1275-1287.

ZAR, J.H. 2008. Biostatistical analisys. 5. ed. Prentice-Hall, Englewood Cliffs, New Jersey, 600p.

ZUIN, V.G. 2020. What Can Be Learnt from the Brazilian Cerrado? Bio. Bur. Sub-Saharan Africa. Available in: https://doi.org/10.1007/978-94-007-08082_11 (Last access in 28/12/2020).
Received: 29/01/2021

Revised: 03/06/2021

Accepted: 04/07/2021

Published online: 30/07/2021 